\section{Red imported fire ants discovered in Sacramento}

An infestation of red imported fire ants was discovered at the California State Fairgrounds in Sacramento, the California Department of Food and Agriculture (CDFA) announced in late October. A visitor from Texas reported suspiciouslooking ants while staying at Cal Expo's RV park, leading officials to believe that they were brought in on a vehicle or plants.

CDFA spokesman Steve Lyle said that the 20 mounds found at Cal Expo have been treated and officials are hopeful that the ants will not survive the winter. "We believe this is an isolated incident, and not indicative of the ants' spread to Northern California," Lyle said.

Red imported fire ants are an exotic pest first discovered in California in 1997. Native to South America, they have thoroughly infested the southern United States. Extremely difficult to eradicate, they are notorious for their viciousness, swarming out of mounds when disturbed and furiously biting and stinging victims.

The ants pose a danger to homes and residents, agriculture and wildlife habitat; UC scientists estimate that if they became established in California costs could run between $\$ 387$ million and $\$ 989$ million per year (see p. 26).

Suspected red imported fire ant mounds should be reported to 1-888-4FIREANT. For more information go to: www.cdfa.ca.gov/ phpps/pdep/rifa/

Research condu in the fynbos shrublands of South Africa, below, which is similar to California chaparral in appearance, demonstrates the important role that natives ants play in regenerating vegetation after a fire.

\section{Nonnative ants disrupt ecosystems}

By replacing native ants, the tiny black Argentine ant - a well-known household pest could be disrupting natural ecosystems. A study by UC Davis graduate student Caroline Christian, published in Nature (October 2001),

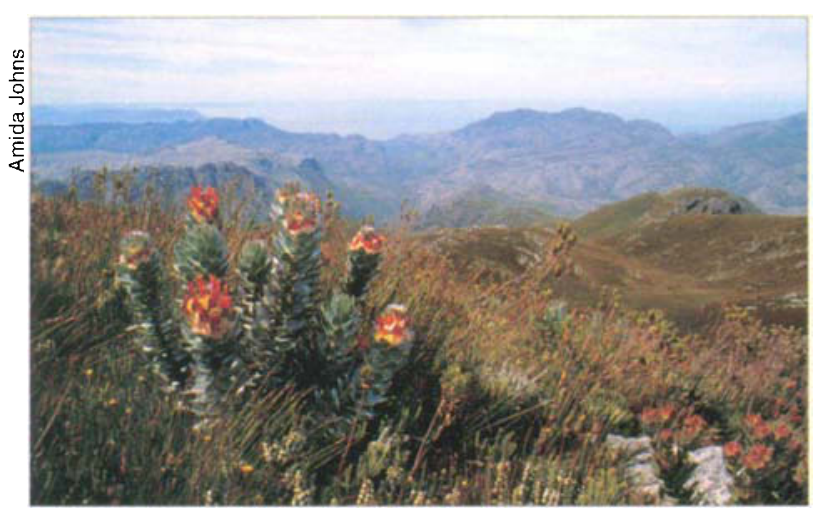

has shown that when key beneficial species are removed by an invading ant, the destructive effects can reverberate through the ecosystem.

Christian, who is affiliated with the UC Davis Center for Population Biology, studied the fynbos shrublands of South Africa, an area similar in climate and vegetation to the chaparral of California. Wildfires sweep the fynbos every 15 to 30 years, killing most mature plants; new plants grow from seeds buried in the ground by native ants. Christian found that when Argentine ants displace native ants, plants that depend on those ants to bury their seeds do not regenerate after fire.

Seed burial by ants is key to survival for about a third of fynbos plant species, Christian said. When fresh seeds fall, ants are attracted to them and carry them off to bury in their nests. Different ant species specialize in seeds of different sizes: Ants that work cooperatively deal with bigger seeds, while ants that tend to work alone bury smaller ones. If the seeds are not picked up quickly, virtually all are eaten by rodents.

After controlled burning, fynbos areas invaded by Argentine ants showed a tenfold drop in the number of new plants from large-seeded species, compared to uninvaded areas, Christian said. Small-seeded species were much less affected.

\section{California a supercolony of Argentine ants}

In a study published in Molecular Ecology (September 2001), scientists from UC Davis and UC San Diego showed that California harbors a huge supercolony of nonnative Argentine ants, extending from Ukiah to beyond the Mexican border.

In Argentina, competition between rival colonies keeps their numbers in check, but most of the California imports recognize each other as family, said Neil Tsutsui, a postdoctoral fellow in the UC Davis Center for Population Biology.

"In ants, usually their biggest competition is within the same species. But here, colonies are so closely related they even exchange workers," said collaborator Andy Suarez, a former UC Davis entomology postdoctoral fellow now at UC Berkeley.

Because they were initiated by a relatively small number of individuals, introduced populations of Argentine ants have reduced genetic diversity and are genetically similar to one another, the scientists found. This close-knit sisterhood allows Argentine ants to form large supercolonies, which then displace native ants and become one of California's leading household and agricultural pests.

Tsutsui and Suarez, working with David Holway and Ted Case at UC San Diego, used a type of DNA fingerprinting to show that Argentine ants in California are genetically similar to ants 